Jurnal Keperawatan Silampari

Volume 3, Nomor 2, Juni 2020

e-ISSN: 2581-1975

p-ISSN: 2597-7482

DOI: https://doi.org/10.31539/jks.v3i2.1189

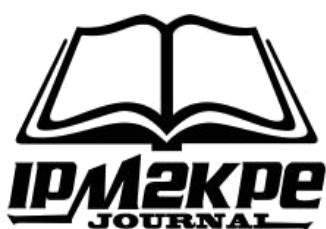

\title{
PENINGKATAN PENGETAHUAN, SIKAP DAN PERILAKU SISWA SD SEBAGAI KADER CILIK PENGAWAS JAJANAN ANAK SEKOLAH DENGAN PELATIHAN
}

\author{
Oslida Martony \\ Politeknik Kesehatan Kementerian Kesehatan Medan \\ oslida64@gmail.com
}

\begin{abstract}
ABSTRAK
Tujuan penelitian ini adalah untuk mengetahui efektivitas pelatihan dalam peningkatan pengetahuan, sikap dan perilaku siswa SD sebagai kader cilik pengawas jajanan anak sekolah di Lubuk Pakam. Metode dalam penelitian ini menggunakan metode penelitian tindakan (action research), menggunakan model pelatihan student facilitator and explaining. Hasil penelitian pemberdayaan dengan model pelatihan student facilitator and explaining dapat meningkatkan pengetahuan, sikap, dan tindakan dari kader cilik tersebut, terdapat perbedaan signifikan terhadap nilai-nilai pengetahuan, sikap dan tindakan berdasarkan siklus I yakni $(p=0,001, p=0,001$, dan $p=0,001)$, dan pada siklus II yaitu ( $p=0,001, p=0,001$, dan $p=0,001)$. Simpulan, pelatihan yang dilakukan pada siswa SD Muhammadiyah efektif sebagai kader cilik pengawas makanan jajanan anak sekolah.
\end{abstract}

Kata Kunci : Jajanan Anak sekolah, Kader Cilik, Pengetahuan, Perilaku, Sikap

\section{ABSTRACT}

The purpose of this study was to determine the effectiveness of the training in improving the knowledge, attitudes, and behavior of elementary school students as a cadre of school hawker supervisors in Lubuk Pakam. The method in this study uses the action research method, using the student facilitator and explaining the training model. The results of the empowerment research with the student facilitator and teaching training model can improve the knowledge, attitudes, and actions of the young cadres, there are significant differences in the values of knowledge, attitudes and activities based on cycle I namely $(p=0.001, p=0.001$, and $p=0.001)$, and in the second cycle $(p=0.001, p=$ 0.001 , and $p=0.001$ ). In conclusion, the training carried out on Muhammadiyah elementary school students is useful as a cadre of child food supervisors of school snacks.

Keywords: Snacks for School Children, Young Cadres, Knowledge, Behavior, Attitudes

\section{PENDAHULUAN}

Masa anak dianggap sebagai fase yang penting karena akan menentukan kualitas kesehatan, kesejahteraan, pembelajaran, dan perilaku dimasa yang akan datang mampu mencapai pertumbuhan dan perkembangan yang optimal (Padila et al., 2019; Panzilion et al., 2020; WHO, 2017). Anak-anak perlu mendapatkan zat gizi sesuai dengan kebutuhan untuk mendukung pertumbuhan dan perkembangan yang optimal. Pola 
makan dan nafsu makan anak-anak mengalami perubahan ketika memasuki usia sekolah pada usia 6 sampai 12 tahun. Anak sudah mulai menentukan sendiri makanan yang akan mereka makan di sekolah. Anak cenderung lebih memilih jajan dan makan di luar rumah dibandingkan makan di rumah. Hal ini menyebabkan kontribusi asupan zat gizi dari jajanan cenderung meningkat (Rosenkranz et al., 2017).

Di Indonesia, makanan jajanan merupakan bagian yang tidak dapat terpisahkan dengan anak sekolah. Kebiasaan jajan anak dapat dilihat dari frekuensi jajan dan kontribusi gizi jajanan (Anggiruling et al., 2019). Hasil penelitian Mudiani et al., tahun 2018 menunjukkan kontribusi energi jajanan tertinggi adalah 607 kkal dan sebanyak 19\% anak-anak tergolong lebih untuk kontribusi jajannya (Mudiani et al., 2018).

Masalah kesehatan di usia dewasa sebagian berkaitan dengan perilaku kesehatan ataupun gaya hidup di usia muda termasuk di usia remaja dan anak-anak. Perilaku hidup sehat sejak usia dini merupakan salah satu upaya yang cukup penting dalam menciptakan sumber daya manusia yang produktif dan berkualitas di masa yang akan datang. Beberapa perilaku berisiko pada anak-anak diantaranya adalah kebiasaan merokok, gizi tidak seimbang, kurang aktifitas fisik, hygiene dan sanitasi individu, jajanan tidak sehat, kebiasaan sarapan yang kurang (Syam et al., 2018).

Mengingat bahaya dari jajanan yang tidak sehat tersebut maka perlu dilakukan suatu pengenalan bagi anakanak usia sekolah mengenai jajanan sehat, jajanan yang berbahaya bagi kesehatan sehingga mereka memiliki pengetahuan, sikap positif dan akan berperilaku mengkonsumsi jajanan yang sehat. Oleh karena itu sangat penting untuk mengenalkan mengenai jajanan sehat, jajanan tidak sehat dan akibatnya bagi kesehatan. Pendidikan kesehatan yang bertujuan untuk mengenalkan mengenai jajanan sehat dan tidak sehat pada anak usia sekolah sangat efektif dengan metode bermain secara berkelompok oleh karena bersadarkan tahapan perkembangan social pada anak usia sekolah adalah berkelompok dan sudah memahami aturan dalam kelompok. Selain itu media yang sesuai untuk penyampaian pesan anak usia sekolah dasar menggunakan gambar yang mudah dipahami anak (Husna, Reliani, 2016).

Penelitian Syam et al., (2018) menunjukkan bahwa tingkat pengetahuan siswa di SD Inpres 1 Tamalanrea tentang jajanan sehat sebelum pemberian edukasi berupa permainan kwartet masih sangat rendah, presentasi siswa dengan tingkat pengetahuan rendah yaitu 56,3\%, tingkat pengetahuan sedang sebanyak $40 \%$ dan tingkat pengetahuan tentang jajanan sehat yang tinggi hanya 3,8\% sedangkan setelah diberikan edukasi terdapat kenaikan tingkat pengetahuan jajanan sehat pada anak SD yaitu pengetahuan rendah menjadi $16,3 \%$, pengetahuan sedang meningkat menjadi $63,7 \%$ dan pengetahuan tinggi menjadi 20,0\%. Rata-rata score tingkat pengetahuan siswa sebelum dan setelah intervensi kartu kwartet meningkat sebanyak rata-rata (Mean \pm SD : $0,375 \pm 0,704)$, signifikan secara statistik $p=0,000$.

Hasil penelitian Fahleni, Tahlil (2016) menunjukkan bahwa ada hubungan yang signifikan antara pengetahuan anak usia sekolah dengan perilaku pemilihan jajanan makanan $(\mathrm{p}=0,015)$, dan antara sikap dengan perilaku pemilihan jajanan makanan $(\mathrm{p}=0,002)$. sikap anak dalam memilih makanan jajanan bervariasi tergantung faktor yang mempengaruhi terhadap sikap anak tersebut. Dimana apabila faktor yang mempengaruhinya adalah faktor yang cenderung positif maka anak tersebut akan memiliki sikap positif namun sebaliknya apabila faktor tersebut cenderung mengarah kearah yang negatif, maka anak tersebut akan memiliki sikap yang negatif pula. 
Hasil penelitian Febryanto (2016) menunjukkan bahwa ada hubungan antara pengetahuan responden dengan perilaku pemilihan jajanan sehat di MI Sulaimaniyah Jombang Tahun 2016. Hal ini menandakan bahwa pengetahuan merupakan faktor yang mendukung responden dalam hal pemilihan jajanan sehat. Pengetahuan mengenai jajanan adalah kepandaian memilih jajanan yang merupakan sumber zat-zat gizi dan kepandaian dalam memilih jajanan yang sehat. Hasil penelitian Husna, Reliani (2016) menunjukkan bahwa terdapat perbedaan pengetahuan sebelum dan sesudah diberikan pendidikan kesehatan dengan streetfood cards.

Selain itu, sikap siswa terhadap jajanan sehat juga meningkat ke arah sikap positif yaitu sebelum intervensi edukasi sikap siswa yang memilih jajanan kurang sehat yaitu sebanyak 81,3\% (sikap negatif), sedangkan siswa yang memiliki sikap memilih jajanan sehat hanya (sikap positif) $18,8 \%$. Persentasi sikap siswa setelah intervensi edukasi kartu kwartet menjadi sikap negatif menurun menjadi $27,5 \%$, dan yang memiliki sikap positif terhadap jajanan sehat menjadi $72,5 \%$. Peningkatan score sikap siswa rata-rata cukup tinggi yaitu Mean $\pm \mathrm{SD}=1,075 \pm 1,347, \mathrm{p}=0,000$ (Syam et al., 2018).

Hasil penelitiani ini berbeda dengan dengan hasil penelitian Aini (2017) di SDN Klurak Candi Sidoarjo Kelas 5, yang memberikan intervensi berupa penyuluhan jajanan sehat berupa video. Peningkatan pengetahuan hanya terjadi pada pada kontrol, bukan pada kelompok intervensi, setelah diteliti ternyata mayoritas kelompok kontrol mendapat informasi sebelumnya dari guru kelas dan teman.

Penelitian terdahulu banyak meneliti tentang variabel pengetahuan, sikap dan perilaku siswa sebagai kader cilik dalam pengawas jajanan, namun penelitian ini lebih menekankan pada pengembangan dalam pemberdayaan anak melalui pelatihan dengan model student facilitator and explaining, tentang makanan jajanan sehat dan makanan jajanan yang mengandung bahan tambahan yang dilarang (formalin, borak, rhodamin b). Selain itu, model ini belum ada yang menerapakannya pada pemberdayaan anak tentang makanan jajanan sehat dan makanan yang mengandung bahan tambahan yang dilarang (formalin, borak, rhodamin b).

\section{METODE PENELITIAN}

\section{Jenis Penelitian}

Dengan pendekatan pelatihan anak sekolah dasar yang akan di jadikan kader cilik pengawas jajanan anak sekolah. Jenis penelitian ini adalah penelitian penelitian tindakan (action research), peneliti ingin menunjukkan bahwa proses keterlibatan langsung untuk mencapai hasil yang praktis dan pemahaman baru dari penelitian serta adanya pola hubungan yang bersifat interaktif dalam memperoleh pemahaman pengetahuan dan perubahan prilaku dengan menggunakan siklus. Dimana metode ini menggunakan empat tahap siklus. Setiap siklus dilakukan: Perencanaan, tindakan, mengamati dan merefleksi.

\section{Lokasi dan Waktu Penelitian}

Penelitian tahap kedua: tahap ini adalah tahap intervensi di lakukan di Sekolah Dasar Muhammadiyah Lubuk Pakam, yang merupakan tempat, dilakukan pengamatan, observasi dan penelitian dilakukan sehingga terbentuk kader cilik yang diinginkan. Sebelum penelitian dilaksanakan dilakukan pendekatan dan perizinan mulai sari Dinas Pendidikan Pemuda dan Olah Raga Deli Serdang diteruskan ke Kepala SD Muhammadiyah Lubuk Pakam dan Yayasan/Majlis Pendidikan Dasar Menengah Muhammadiyah Cabang Lubuk Pakam, untuk dilakukan intervensi pemberdayaan 
melalui pelatihan dengan model student facilitator and explaining pada anak sekolah yang terpilih, sebelum dan sesudah intervensi dilakukan pre test dan post test, dimana waktu penelitian ini dilakukan mulai September 2015 sampai Agustus 2016.

\section{Pelaksanaan Penelitian}

Pelaksanaan penelitian di lakukan dua (2) tahap secara berurutan yang merupakan bagian yang tidak terpisahkan satu dengan yang lainnya.

\section{Pengambilan Sampel}

Metode pengambilan sampel dilakukan dengan cara purposif sumpling. Sampel yang digunakan sebanyak 24 sampel makanan jajanan yang dicurigai mengandung formalin dan borak serta 18 sampel makanan jajanan yang dicurigai mengadung rhodamin b di ambil dari 24 lokasi sekolah Dasar di Lubuk Pakam.

\section{Pelatihan Siswa Menjadi Kader Cilik}

Pada tahap ini dilakukan intervensi pada anak sekolah dasar melalui pelatihan dengan pendekatan siswa sekolah dasar yang akan di jadikan kader cilik pengawas jajanan anak sekolah. Jenis penelitian ini adalah penelitian penelitian tindakan (action research). Peneliti ingin menunjukkan bahwa proses keterlibatan langsung untuk mencapai hasil yang praktis dan pemahaman baru dari penelitian serta adanya pola hubungan yang bersifat interaktif dalam memperoleh pemahaman pengetahuan dan perubahan prilaku dengan menggunakan siklus Kemmis dan Taggart dengan siklus perencanaan, tindakan, mengamati dan merefleksi.

\section{Pre Test}

Pada tahap ini dilakukan pre test tarhadap sampel/siswa, dengan menggunakan daftar pertanyaan, untuk mengukur pengetahuan, sikap dan tindakan siswa/kader cilik pengawas jajanan anak sekolah tentang jajanan sehat dan jajanan yang menggunakan bahan tambahan berbahaya (formalin, borak dan rhodamin B ).

\section{Pelatihan}

Pelatihan ini dengan tujuan dapat meningkatkan pengetahuan dan perilaku kader/siswa dan bisa menjadi penyampai pesan kepada teman temannya. Untuk mewujudkan harapan-harapan tersebut, maka penelitian tindakan dirancang dengan proses pengkajian bersiklus yang terdiri dari 4 (empat) tahap kegiatan yaitu: merencanakan, melakukan tindakan, mengamati, dan merefleksi. Tahapan-tahapan ini terus berulang sampai suatu permasalahan dianggap teratasi untuk kemudian diikuti oleh kemunculan permasalahan lain yang juga harus diperlakukan sama.

\section{Observasi}

Pada tahap ini dilakukan observasi terhadap proses pelaksanaan tindakan. Peneliti menyiapkan alat untuk melakukan pengamatan terhadap pelaksanaan pelatihan Model Student Fasilitator and Explaining. Catat hal-hal yang mungkin terjadi selama tindakan berlangsung. 


\section{Refleksi}

Tahapan refleksi ini adalah hasil yang dicapai pada tahap observasi di kumpulkan serta di analisis dan di refleksikan apakah proses pelatihan yang di terapkan dapat menciptakan kader keamanan makanan jajanan yang di harapkan.

\section{Metode Pengumpulan Data}

Pada penelitian ini teknik pengumpulan data dilakukan dengan: kuesioner dan observasi/wawancara. Pada instrumen kuesioner digunakan untuk mengumpulkan data pengetahuan, sikap dan tindakan kader cilik tentang jajanan yang mengandung bahan tambahan yang berbahaya (formalin, borak dan zat pewarna rhodamin b), sedangkan pada observasi/pengamatan untuk melakukan pencatatan terhadap aktivitas perilaku kader cilik serta kemampuannya menyampaikan kepada teman-temannya.

\section{HASIL PENELITIAN .}

Tabel. 1

Perbedaan Nilai Pengetahuan Pre test dan Post test pada Siklus I

\begin{tabular}{|c|c|c|c|c|c|c|c|}
\hline \multirow[t]{2}{*}{ No } & \multirow[t]{2}{*}{ Peri Laku } & \multirow[t]{2}{*}{$\mathrm{n}$} & \multirow{2}{*}{$\begin{array}{l}\text { Nilai } \\
\text { Rerata }\end{array}$} & \multicolumn{2}{|c|}{ Nilai } & \multirow[t]{2}{*}{ Std. Deviasi } & \multirow[t]{2}{*}{ Nilai $p$} \\
\hline & & & & Min & Max & & \\
\hline \multirow[t]{3}{*}{1.} & Pengetahuan & & & & & & \multirow{3}{*}{0,000} \\
\hline & Pre Test & 25 & 42,60 & 30,00 & 50,00 & 4,592 & \\
\hline & Post Test I & 25 & 63,00 & 55,00 & 75,00 & 4,787 & \\
\hline \multirow[t]{3}{*}{2.} & Sikap & & & & & & \multirow{3}{*}{0,000} \\
\hline & Pre Test & 25 & 39,20 & 27,00 & 53,00 & 6,856 & \\
\hline & Post Test I & 25 & 56,36 & 40,00 & 67,00 & 8,902 & \\
\hline \multirow[t]{3}{*}{3.} & Tindakan & & & & & & \multirow{3}{*}{0,000} \\
\hline & Pre Test & 25 & 44,56 & 33,00 & 53,00 & 6,646 & \\
\hline & Post Test I & 25 & 61,64 & 46,00 & 73,00 & 7,011 & \\
\hline
\end{tabular}

Perbedaan nilai pre tes dan pos tes hasil terhadap pengetahuan kader cilik pada pelaksanaan siklus pertama dengan nilai rata-rata pre tes 42,6 dan nilai rata-rata pos tes 63,0 .

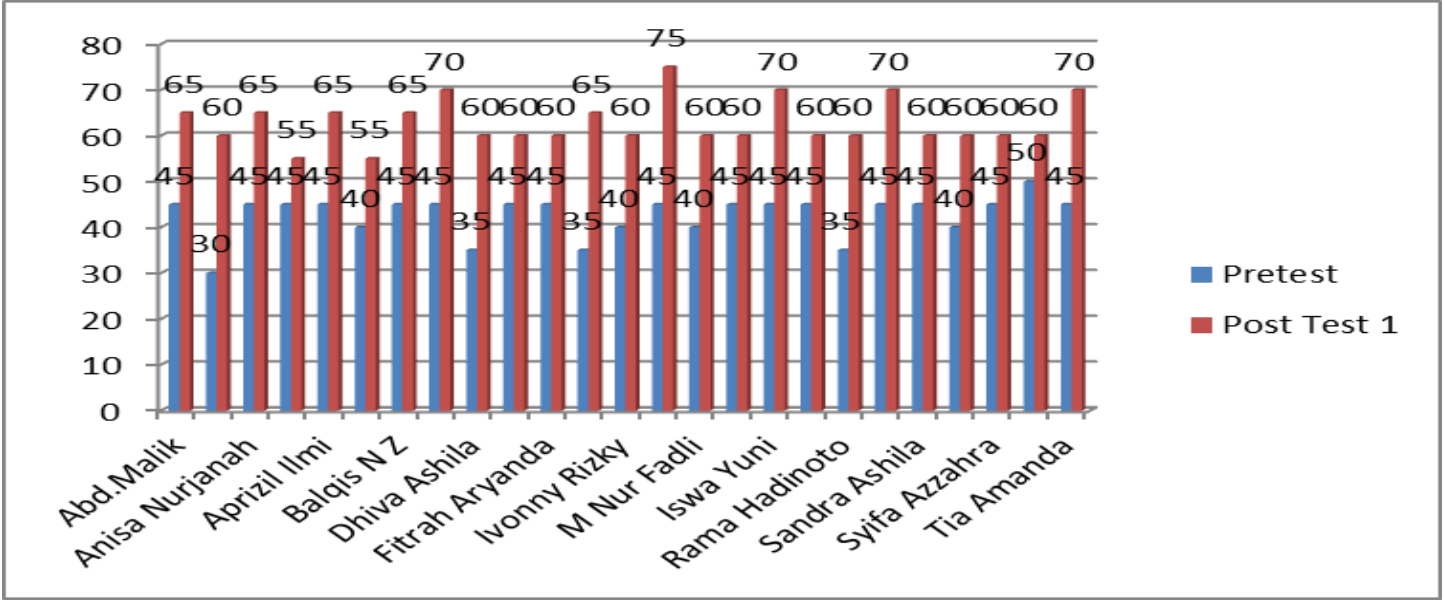

Gambar. 1

Diagram Perbedaan Nilai Pre Test dan Post Test Pengetahuan Kader Cilik pada Siklus I 
Berdasarkan data Gambar 1 diatas dapat dilihat, adanya peningkatan pengetahuan Kader Cilik tentang makanan jajanan sehat dengan nilai rata-rata pada pre test 42,6 setelah dilakukan intervensi pada siklus ke 1 nilai post test pengetahuan, terjadi peningkatan nilai rata-rata pengetahuan kader cilik menjadi 63,0, dengan nilai tertinggi 75 dan nilai terendah 55. Hasil uji statistk menyimpulkan ada perbedaan yang signifikan dengan nilai $p=0,00<0,05$, berarti ada perbedaan yang signifikan pengetahuan kader cilik tentang makanan jajanan sehat dan makanan jajanan yang mengandung bahan berbahaya sesudah pemberdayaan pada siklus I.

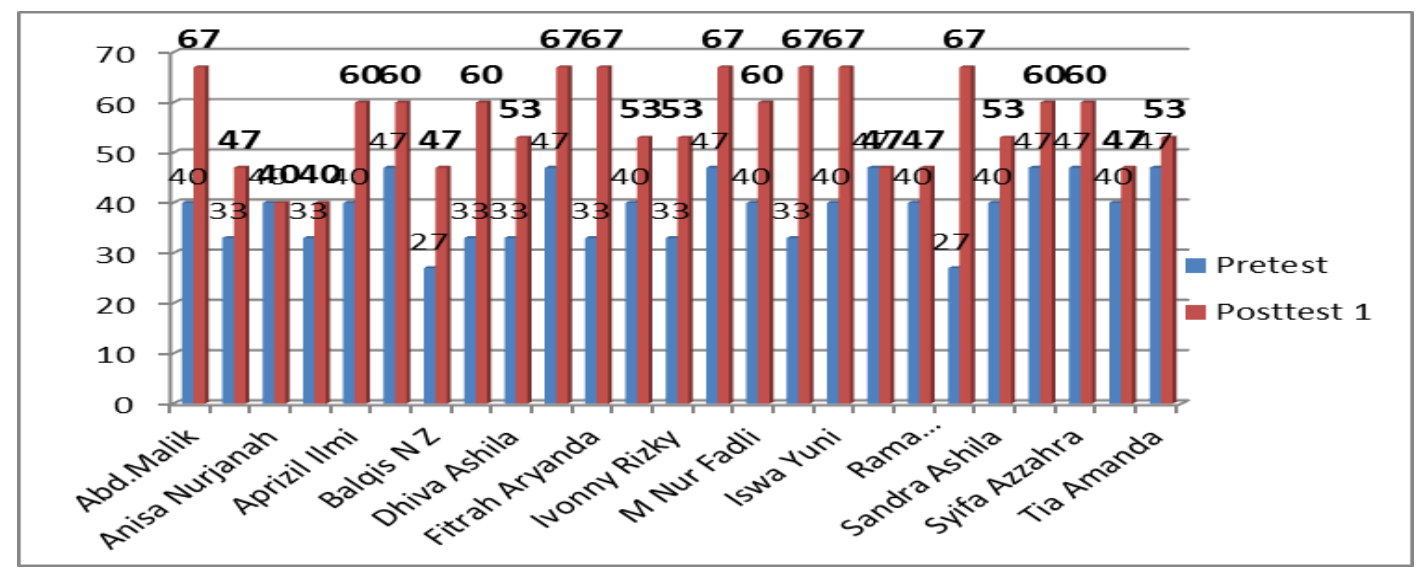

Gambar. 2

Diagram perbedaan Nilai Pre Test dan Post Test Sikap Kader Cilik pada siklus I

Berdasarkan data yang diperoleh, diketahui adanya peningkatan sikap Kader Cilik terhadap makanan jajanan dari nilai rata-rata pada pre tes dengan nilai rata-rata 39.20 setelah dilakukan intervensi pada siklus ke 1 maka terjadi peningkatan nilai rata-rata sikap kader cilik meningkat menjadi 56.36, dengan nilai tertinggi 67 dan terendah 40. Hasil uji statistk menyimpulkan ada perbedaan yang signifikan dengan nilai $p=0,00<$ 0,05 , berarti ada perbedaan yang signifikan sikap kader cilik dalam memilih makanan jajanan sehat dan makanan jajanan yang mengandung bahan berbahaya sesudah pemberdayaan pada siklus I.

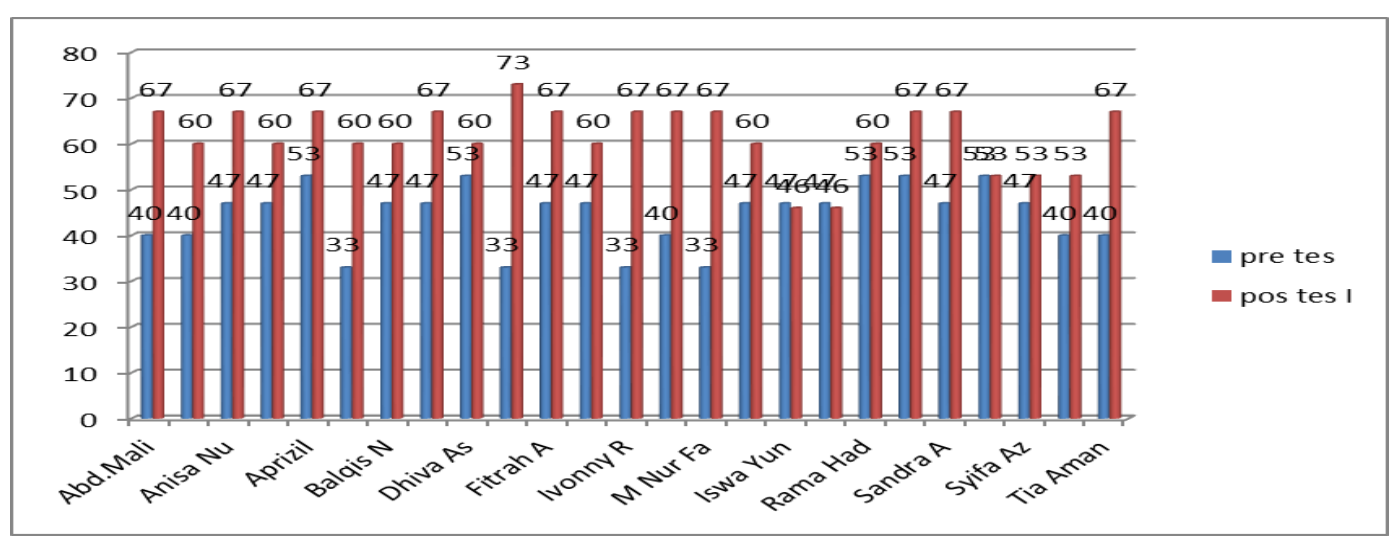

Gambar. 3

Diagram Perbedaan Nilai Tindakan Pre test dan Pos Test Kader Cilik pada siklus I 
Berdasarkan data yang diperoleh, diketahui adanya peningkatan tindakan Kader Cilik terhadap makanan jajanan dari nilai rata-rata pada pre test dengan nilai rata-rata 44,56 setelah dilakukan intervensi pada siklus ke 1 maka terjadi peningkatan nilai ratarata tindakan Kader Cilik meningkat menjadi 61,64 dengan nilai tertinggi 73 dan terendah 46, untuk mengetahui perbedaan rata-rata nilai tindakan kader cilik pada pre test dan post test I dilakukan uji $\mathrm{T}$ Dependen pada nilai alpha 5\%. Hasil uji statistk menyimpulkan ada perbedaan yang signifikan dengan nilai $p=0,00<0,05$, berarti ada perbedaan yang signifikan tindakan kader cilik dalam memilih makanan jajanan sehat dan makanan jajanan yang mengandung bahan berbahaya sesudah pemberdayaan pada siklus I.

Tabel. 2

Analisis Nilai Post Tes Aktifitas

Kader Cilik

\begin{tabular}{cccc}
\hline Nilai Aktifitas & Frekuensi & $\%$ & Rata-rata \\
\hline Sangat Baik & - & & \\
Baik & 3 & 12 & \\
Cukup & 22 & 88 & 2,52 \\
Kurang & - & & \\
Jumlah & 25 & 100 & \\
\hline
\end{tabular}

Perkembangan aktivitas kader cilik peserta pelatihan pada siklus pertama dari pertemuan 1-7 sebagian besar $88 \%$ (22 orang) kader cilik yang ketrampilannya pada kategori cukup. Karena penilaian pengetahuan, sikap, tindakan serta aktifitas masih belum mencapai target yang di inginkan, maka penelitian dilanjutkan ke siklus dua.

Tabel. 3

Hasil Penilaian Post Test pada Siklus Kedua

\begin{tabular}{llccccc}
\hline No & Nama & \multicolumn{3}{c}{ Nilai } & \multirow{2}{*}{ Keterangan } \\
\cline { 3 - 5 } & & Pengetahuan & Sikap & Tindakan & Ketrampilanan & \\
\hline 1 & Abd.Malik & 90 & 93 & 100 & 3,85 & Sangat Baik \\
2 & Aliya A.Irawan & 85 & 87 & 87 & 3,71 & \\
3 & Anisa Nurjannah & 90 & 87 & 93 & 3,71 & \\
4 & Aprillia Putri & 95 & 87 & 93 & 3,57 & \\
5 & Aprizil Ilmi & 95 & 87 & 93 & 3,85 & Sangat Baik \\
6 & Auliya Nirmala & 90 & 87 & 87 & 3,57 & \\
7 & Balqis NZ & 85 & 80 & 93 & 3,71 & \\
8 & Bani Liwau H & 95 & 87 & 93 & 3,71 & \\
9 & Diva Ashila & 90 & 80 & 87 & 3,57 & \\
10 & Fadlan Wafiq L & 95 & 93 & 100 & 4,00 & Sangat Baik \\
\hline 11 & Fitrah Aryanda & 90 & 80 & 93 & 3,71 & \\
12 & Gusnedi Alwi C & 85 & 80 & 80 & 3,57 & \\
13 & Ivonny Rizky & 90 & 93 & 93 & 3,71 & \\
14 & M.Syafiq Aflah & 90 & 100 & 93 & 3,71 & \\
15 & M.Nur Fadli & 85 & 87 & 93 & 3,71 & \\
16 & Nirwana Indah J & 90 & 87 & 80 & 3,57 & \\
17 & Iswa Yuni & 95 & 93 & 93 & 3,71 & \multirow{2}{*}{ Sangat Baik } \\
18 & Putri Asyifa & 85 & 87 & 87 & 4,00 & \\
19 & Rama Hadinoto & 90 & 80 & 80 & 3,71 & \\
20 & Rika Dwi A & 90 & 100 & 87 & 3,57 & \\
\hline
\end{tabular}




\begin{tabular}{lllllll}
\hline 21 & Sandra Asila & 85 & 100 & 87 & 3,57 & \\
22 & Shakila Sofiani & 85 & 80 & 80 & 3,85 & \\
23 & Syifa Azzahra & 90 & 93 & 80 & 3,71 & \\
24 & Siti Nazwa R & 85 & 87 & 87 & 3,71 & \\
25 & Tia Amanda & 95 & 93 & 93 & 4,00 & Sangat Baik \\
\hline
\end{tabular}

Dari hasil Post tes pada siklus kedua hasil yang dinginkan tercapai sesuai dengan indikator keberhasilan yang diharapkan. Dimana peningkatan pengetahuan, sikap, tindakan dan aktifitas/ketrampilan menyuluh sudah sangat meningkat dan maju . Hal ini disebabkan karena pada siklus kedua ini intensnya para kader cilik untuk berlatih penyuluhan yang diulang-ulang dilakukan baik dengan media lembar balik maupun dengan lagu-lagu yang berisi tentang pesan jajanan yang sehat dan menghidari jajanan yang berbahaya.

\section{PEMBAHASAN}

\section{Pengetahuan, Sikap dan Perilaku Siswa SD Sebagai Kader Cilik Pengawas Jajanan Anak Sekolah}

Hasil penelitian ini menunjukkan terjadinya peningkatan pengetahuan kader cilik tentang jajanan sehat sebelum dan setelah diberikan pelatihan. Sejalan dengan penelitian yang dilakukan Wowor et al., (2018) ada hubungan antara sikap terhadap makanan jajanan dengan perilaku konsumsi jajanan pada pelajar di Sekolah Dasar Negeri 16 dan Sekolah Dasar Negeri 120 Manado.

Penelitian yang dilakukan Briawan (2016) perbandingan pengetahuan jajanan anak antar provinsi sebelum dan setelah intervensi relatif berbeda. Sebagian besar anak SD mempunyai tingkat pengetahuan dengan kategori baik di Provinsi DKI Jakarta, Banten, Jawa Barat, DI Yogyakarta, dan Jawa Timur. Pada anak SD di Sumatera Utara memiliki tingkat pengetahuan terbanyak dengan kategori sedang $(2,6 \%)$ dan kurang $(2,5 \%)$. Sedangkan tingkat pengetahuan kategori baik hanya sebesar 1,6\%. Demikian pula di Sulawesi Selatan tingkat pengetahuan anak sebagian besar sedang $(92,9 \%)$ dan kurang $(2,7 \%)$ dibandingkan yang baik $(1,1 \%)$. Adapun di Kalimantan Timur anak SD kebanyakan mempu-nyai tingkat pengetahuan sedang $(3,2 \%)$ dibandingkan yang baik $(2,9 \%)$ dan kurang $(0,6 \%)$. Variasi perbedaan efektivitas edukasi antar provinsi kemungkinan karena terdapat perbedaan di dalam pelaksanaan intervensi. Intervensi dilakukan oleh mitra LSM lokal yang berbeda antar lokasi, sehingga kemampuan dalam penyampaian edukasi kepada edukator sekolah (guru dan dokter cilik) juga beragam. Kontrol yang dilakukan mitra terhadap pelaksanaan edukasi tidak bisa maksimal karena keragaman jadwal pelaksanaan edukasi di masing-masing sekolah.

Hasil penelitian Tambunan et al., (2019) bahwa dari 114 responden (100\%) terdapat sebanyak 58 responden berpengetahuan baik, mayoritas dengan perilaku jajan yang baik sebanyak 31 orang $(27,2 \%)$, sedangkan sebanyak 56 responden memiliki pengetahuan tidak baik mayoritas dengan perilaku jajan yang tidak baik sebanyak 38 responden $(33,3 \%)$. Hasil uji statistik chi square pada variabel pengetahuan dengan nilai $\mathrm{p}=0,022<0,05$ yang artinya ada hubungan pengetahuan dengan perilaku jajan siswa.

Berdasarkan hasil tingkat pengetahuan siswa di SD Inpres 1 Tamalanrea tentang jajanan sehat sebelum pemberian edukasi berupa permainan kwartet masih sangat rendah, presentasi siswa dengan tingkat pengetahuan rendah yaitu 56,3\%, tingkat pengetahuan sedang sebanyak $40 \%$ dan tingkat pengetahuan tentang jajanan sehat yang tinggi hanya $3,8 \%$ sedangkan setelah diberikan edukasi terdapat kenaikan tingkat pengetahuan jajanan sehat pada anak SD yaitu pengetahuan rendah menjadi $16,3 \%$, 
pengetahuan sedang meningkat menjadi $63,7 \%$ dan pengetahuan tinggi menjadi $20,0 \%$. Rata-rata score tingkat pengetahuan siswa sebelum dan setelah intervensi kartu kwartet meningkat sebanyak rata-rata (Mean \pm SD : 0,375 $\pm 0,704)$, signifikan secara statistik $p=$ 0,000 (Syam et al., 2018).

Pengetahuan tentang jajanan sehat berhubungan dengan pemilihan jajanan. Pengetahuan dapat diperoleh secara internal maupun eksternal. Pengetahuan secara internal yaitu berasal dari dirinya sendiri berdasarkan pengalaman hidup, sedangkan pengetahuan secara eksternal yaitu pengetahuan yang berasal dari orang lain sehingga pengetahuan anak tentang jajanan sehat yang bergizi bertambah. Makanan yang kurang memenuhi syarat kesehatan akan mengancam kesehatan anak. Nafsu makan anak yang berkurang dan jika berlangsung lama akan berpengaruh pada kesehatannya (Tambunan et al., 2019).

Tingkat pengetahuan anak tentang jajanan sehat berhubungan dengan perilaku jajan anak di sekolah, hal ini dapat berpengaruh terhadap kesehatannya. Dalam keadaan sehat seseorang akan lebih mudah mengonsumsi makanan terutama anak sekolah. Menurut pakar pendidikan untuk membantu proses pendidikan anak sebaiknya orang tua menambah pengetahuan, sebab semakin tinggi pengetahuan orang tua maka semakin banyak pula pengetahuan yang diberikan kepada anak-anaknya (Tambunan et al., 2019).

Hasil penelitian ini menunjukkan terjadinya peningkatan sikap kader cilik tentang jajanan sehat sebelum dan setelah diberikan pelatihan. Sejalan dengan penelitian Wowor et al., (2018) Ada hubungan antara sikap terhadap makanan jajanan dengan perilaku konsumsi jajanan pada pelajar di Sekolah Dasar Negeri 16 dan Sekolah Dasar Negeri 120 Manado.

Penelitian Syam et al., (2018) juga menunjukkan sikap siswa terhadap jajanan sehat juga meningkat ke arah sikap positif yaitu sebelum intervensi edukasi sikap siswa yang memilih jajanan kurang sehat yaitu sebanyak $81,3 \%$ (sikap negatif), sedangkan siswa yang memiliki sikap memilih jajanan sehat hanya (sikap positif) $18,8 \%$. Persentasi sikap siswa setelah intervensi edukasi kartu kwartet menjadi sikap negatif menurun menjadi $27,5 \%$, dan yang memiliki sikap positif terhadap jajanan sehat menjadi $72,5 \%$. Peningkatan score sikap siswa rata-rata cukup tinggi yaitu Mean \pm SD $=$ $1,075 \pm 1,347, \mathrm{p}=0,000$.

Hasil penelitian Tambunan et al., (2019) juga menunjukkan bahwa dari 114 responden $(100 \%)$ terdapat sebanyak 54 responden dengan sikap positif mayoritas dengan perilaku jajan yang baik sebanyak 29 orang $(25,4 \%)$, sedangkan sebanyak 60 responden dengan sikap negatif mayoritas dengan perilaku jajan yang tidak baik sebanyak 40 responden $(35,1 \%)$. Hasil uji statistik chi square pada variabel sikap dengan nilai $\mathrm{p}=0,028<0,05$ yang artinya ada hubungan sikap siswa dalam memilih jajan dengan perilaku jajan.

\section{Pemberdayaan Siswa Menjadi Kader Cilik Pengawas Jajanan Anak Sekolah}

Penekanan dalam pembahasan ini, lebih difokuskan penelitian tahap kedua yang merupakan proses kegiatan penelitian yang dimulai dengan kegiatan pre test, siklus pertama, dan siklus kedua serta dampak dari penelitiaan. Berdasarkan hasil evaluasi intervensi pemberdayaan melalui pelatihan model student facilitator and explaining yang dilakukan kepada kader cilik pengawas jajanan anak sekolah yang dapat meningkatkan nilai rata pengetahuan, sikap dan tindakan kader cilik dalam penelitian ini. 
Salah satu strategi yang dapat dilakukan adalah melatih siswa siswi sejak dini untuk membentuk kader cilik yang cerdas dalam memilih dan membuat jajanan sehat. Pembentukan kader cilik ini merupakan bentuk program peer education, dimana para siswa dilatih menjadi peer educator untuk teman sebayanya. Harapan dari terbentuknya kader cilik tersebut adalah informasi tentang pentingnya jajanan sehat dapat tertular kepada siswa-siswa yang lainnya, sehingga perilaku dalam memilih jajanan sehat akan terbentuk (Handayani et al., 2018).

Dengan melibatkan kepala sekolah, guru, siswa serta tim pengembang kantin sehat dapat memberikan pengaruh pada peningkatan pemahaman siswa mengenai pangan jajan yang sehat, aman dan bergizi. Kegiatan penerapan SOP pelayanan dan adab makan siswa, SOP pengelolaan kantin sehat, dan SOP sanitasi serta higienitas memberikan pengaruh terhadap perilaku makan sehat siswa di sekolah serta perilaku adab makan yang baik (Sayekti, Istikomayanti, 2017).

Penelitian Anugraheni et al., (2018) menunjukkan bahwa pemberian pelatihan pemeriksaan fisik pada kader mungil SD Negeri Pudakpayung 02 dapat meningkatkan pengetahuan kader mungil terkait kebersihan tangan, kesehatan gigi dan mulut, kesehatan telinga dan mata sehingga kader mungil mampu melakukan pemeriksaan secara mandiri dan memberikan informasi kesehatan kepada siswa SDNegeri Pudakpayung 02.

Peran kader sangatlah penting dilingkungan sekolah terutama sekolah dasar. Karena dari awal sudah dibentuk jiwa pemimpin yang mampu mengarahkan dirinya dan teman disekitarnya untuk hidup sehat. Apabila semua siswa mampu mengaplikasikan perilaku hidup sehat yang sering dicontohkan oleh kader uks, maka kejadian sakit pada siswa semakin menurun. Disebabkan oleh siswa selalu menjaga pola hidup sehat (Purwantiningsih et al., 2017).

Hasil penelitian Fridayanti, Prameswari (2016) berdasarkan hasil penelitian, dapat diketahui bahwa pelaksanaan kegiatan pelayanan kesehatan oleh UKS SD Negeri Lamper Kidul 02 meliputi kegiatan promotif yaitu dokter kecil, pembinaan kantin sekolah sehat, pembinaan lingkungan sekolah serta pembinaan perilaku hidup bersih dan sehat (PHBS). Kegiatan preventif yang dilakukan oleh UKS SD Negeri Lamper Kidul 02 berupa pemeliharaan kesehatan secara umum, penjaringan (screening) anak yang baru masuk masuk sekolah, pemeriksaan berkala serta imunisasi.

Hasil penelitian Magfiroh, Sudibjo (2016) juga menjelaskan bahwa dokter kecil dilaksanakan dan diberi infrastruktur yang memadai maka dokter kecil dapat menjadi kader kesehatan di sekolah yang dapat menjadi promotor dan motivator atas terselenggaranya hidup sehat bagi teman-teman lingkungannya sehingga pada akhirnya dapat meningkatkan derajat kesehatan siswa sekolah.

\section{SIMPULAN}

Pemberdayaan siswa SD dengan pendekatan student facilitator and explaining dapat menciptakan kader cilik pengawas jajanan anak sekolah yang berani cerdas dan komunikatif. Pelatihan yang dilakukan pada siswa SD Muhammadiyah efektif sebagai kader cilik pengawas makanan jajanan anak sekolah. 


\section{SARAN}

\section{Pemerintah Deli Serdang}

Diharapkan kegiatan ini dapat dimasukkan kedalam peraturan daerah Kabupaten Deli Serdang tentang kabupaten layak anak.

\section{Dinas Pendidikan}

Di harapkan program ini menjadi program yang dapat dikembangkan di sekolah SD di Kota Lubuk Pakam.

\section{Sekolah}

Kepada Majelis pendidikan dasar dan menengah Muhammadiyah cabang Lubuk Pakam agar dapat memfasilitsi kegiatan ini dalam bentuk anggaran pembiayaan. Diharapkan pihak sekolah mengintegrasikan kegiatan ini didalam kurikulum pelajaran di sekolah.

\section{DAFTAR PUSTAKA}

Aini, N. (2017). Mengubah Perilaku Jajan Sembarangan pada Siswa Sekolah Dasar Melalui Penyuluhan Kesehatan (Changing the Behaviour Street Food Consumption for School Children at Elementary School Klurak Candi Sidoarjo by Health Education). Journal Nursing Care and Biomolecular, 1(1), 28. https://doi.org/10.32700/jnc.v1i1.7

Anggiruling, D. O., Ekayanti, I., \& Khomsan, A. (2019). Analisis Faktor Pemilihan Jajanan, Kontribusi Gizi dan Status Gizi Siswa Sekolah Dasar. Media Kesehatan Masyarakat Indonesia, 15(1), 81. https://doi.org/10.30597/mkmi.v15i1.5914

Anugraheni, H. D., Afrikhah, U., \& Prihatiningrum, B. I. (2018). Pemberdayaan Siswa Sekolah Dasar dalam Upaya Meningkatkan Status Kesehatan Warga Sekolah. Jurnal Info, 19(2), 95-103

Briawan, D. (2016). Perubahan Pengetahuan, Sikap, dan Praktik Jajanan Anak Sekolah Dasar Peserta Program Edukasi Pangan Jajanan. J. Gizi Pangan, 11(3), 201-210. https://doi.org/10.25182/jgp.2016.11.3.\%p

Fahleni, R., \& Tahlil, T. (2016). Perilaku Pemilihan Makanan Jajanan pada Anak Usia Sekolah di Aceh Besar. Jurnal Ilmiah Mahasiswa Fakultas Keperawatan, 1(1), 16

Febryanto, M. A. B. (2016). Hubungan antara Pengetahuan dan Sikap dengan Perilaku Konsumsi Jajanan di MI Sulaimaniyah Jombang. Jurnal Keperawatan Muhammadiyah, 1(2), 7-17

Fridayanti, D. V., \& Prameswari, G. N. (2016). Peran Usaha Kesehatan Sekolah (UKS) Dalam Upaya Penanggulangan Obesitas Anak Usia Sekolah. Journal of Health Education, 1(2), 8-14. https://doi.org/10.1080/10556699.1992.10616274

Handayani, D., Herdiani, N., \& Ayu, F. (2018). Pelatihan Pembuatan Bekal Sehat Secara Mandiribagi Anak Usia Sekolah di SDN Margorejo V Surabaya. Community Development Journal, 2(1), 55-63. https://journal2.unusa.ac.id/index.php/CDJ/article/view/378

Husna, A. R., \& Reliani. (2016). Streetfood Cards sebagai Media Merubah Pengetahuan, Sikap, dan Perilaku Anak Usia Sekolah dalam Mengkonsumsi Jajanan di SDN 1 Wonorejo Rungkut Surabaya. Jurnal Keperawatan Muhammadiyah, 1, 7-14

Magfiroh, E., \& Sudibjo, P. (2016). Pelaksanaan Program Dokter Kecil dalam Usaha Kesehatan Sekolah (UKS) di Sekolah Dasar Se-Kecamatan Pundong Kabupaten Bantul Tahun 2016. Universitas Negeri Yogyakarta 
Mudiani, N. P. R., Nursanyato, H., \& Gumala, N. M. Y. (2018). Status Gizi dan Kontribusi Konsumsi Makanan Jajajan Anak Sekolah di SD 2 Penatih Denpasar Timur. Jurnal Ilmu Gizi, 7(1), 26-28

Padila, P., Andari, F. N., \& Andri, J. (2019). Hasil Skrining Perkembangan Anak Usia Toddler antara DDST dengan SDIDTK. Jurnal Keperawatan Silampari, 3(1), 244-256. https://doi.org/10.31539/jks.v3i1.809

Panzilion, P., Padila, P., Amin, M., \& Andri, J. (2020). Perkembangan Motorik Prasekolah antara Intervensi Brain Gym dengan Puzzle. Jurnal Keperawatan Silampari, 3(2), 510-519. https://doi.org/https://doi.org/10.31539/jks.v3i2.1120

Purwantiningsih, E., Rifai, R., \& Kurdi, F. (2017). Hubungan Peran Kader UKS (Tiwisada) dengan Absensi Sakit Siswa di SDN Jombatan 5 Jombang. Jurnal Ilmiah Keperawatan, 3(2), 1-6

Rosenkranz, R. R., Rodicheva, N., Updike, N., Rosenkranz, S. K., \& Dzewaltowski, D. A. (2017). Behaviorally Oriented Nutrition Education at a Russian Summer Camp Improves Children's Dietary Choices: A Quasi-Experimental Study. Nutrire, 42(1), 1-8. https://doi.org/10.1186/s41110-017-0044-Z

Sayekti, N. S., \& Istikomayanti, Y. (2017). Pendidikan Perilaku Makan Sehat melalui Pengembangan Kantin Sehat di SMP/MTS Kota Malang. Jurnal Akses Pengabdian Indonesia, 1(2), 49-58

Syam, A., Indriasari, R., \& Ibnu, I. (2018). Gambaran Pengetahuan dan Sikap Siswa terhadap Makanan Jajanan Sebelum dan Setelah Pemberian Edukasi Kartu Kwartet pada Anak Usia Sekolah Dasar di Kota Makassar. Jurnal Tepat, 1(2), 127-136

Tambunan, G. N., Asriwati, A., \& Syamsul, D. (2019). Faktor-Faktor yang Memengaruhi Perilaku Jajan Anak di SD Wilayah Kerja Puskesmas Matiti Kecamatan Doloksanggul Kabupaten Humbang Hasundutan. Promotif: Jurnal $\begin{array}{lll}\text { Kesehatan } \quad \text { Masyarakat, } & \text { 65-75), }\end{array}$ http://jurnal.unismuhpalu.ac.id/index.php/PJKM

WHO. (2017). Early Child Development. https://www.tandfonline.com/loi/gecd20?open=187\&year=2017\&repitition=0\#vol 187_2017

Wowor, P., Engkeng, S., \& Kalesaran, A. F. (2018). Faktor-Faktor yang Berhubungan dengan Perilaku Konsumsi Jajanan pada Pelajar di Sekolah Dasar Negeri 16 dan Sekolah Dasar Negeri 120 Kota Manado. Jurnal Kesmas, 7(5), 1-10 